\title{
Analisis Peran Remunerasi dan Budaya Organisasi Terhadap Kompetensi Pegawai Guna Meningkatkan Kinerja Pegawai di Lembaga Penerbangan dan Antariksa Nasional
}

\author{
Analysis The Influence of Organizational Culture Against Remuneration on Employee Competency \\ To Improve Employee Performance at Lembaga Penerbangan dan Antariksa Nasional
}

\author{
Leny Maryesa ${ }^{1^{*}}$, Anggraini Sukmawati ${ }^{2 \sharp}$, dan Hari Wijayanto ${ }^{3 *}$ \\ 1Program Magister Manajemen Sekolah Pascasarjana Institute Pertanian Bogor \\ Handphone 081213333302, Email: maryesa.leny@gmail.com \\ ${ }^{2}$ Departemen Manajemen, Fakultas Ekonomi Manajemen Institut Pertanian Bogor \\ ${ }^{3}$ Departemen Statistik, FMIPA Institut Pertanian Bogor
}

\begin{abstract}
ABSTRAK
Kinerja Pegawai Negeri Sipil (PNS) idealnya merupakan pelayanan terhadap masyarakat dalam menjalani dan memenuhi kebutuhan sehari-hari. Tujuan akhir para PNS tentunya tak lain ialah meningkatkan kesejahteraan masyarakat. Remunerasi pemerintahan adalah merupakan bagian yang tidak terpisahkan dari kebijakan reformasi birokrasi. Dilatarbelakangi oleh kesadaran sekaligus komitmen pemerintah untuk mewujudkan clean and good governance.Tujuan reformasi birokrasi adalah membangun kepercayaan masyarakat (public trust building) dan menghilangkan citra negatif birokrasi pemerintahan.Visi reformasi birokrasi adalah terwujudnya aparatur Negara profesional dan kepemerintahan yang baik (good governance). Misi reformasi birokrasi adalah mengubah pola/alam pikiran (mindset), pola budaya (cultural set), dan sistem tata kelola pemerintahan. Pelaksanaan remunerasi diterapkan di Lembaga Penerbangan dan Antariksa Nasional (LAPAN) pada Juli Tahun 2013 yang diberikan sesuai dengan kompetensi yang dimiliki pegawai, prestasi kerja para pegawai, dan disiplin kerja. Tujuan kajian menganalisis hubungan remunerasi dan budaya organisasi, analisis pengaruh remunerasi terhadap kompetensi pegawai, budaya organisasi terhadap kompetensi pegawai, kompetensi pegawai terhadap kinerja pegawai, remunerasi terhadap kinerja pegawai dan pengaruh budaya organisasi terhadap kinerja pegawai. Analisis data yang digunakan dalam penelitian ini adalah Structural Equation Modeling (SEM). Hasil kajian secara simultan dan parsial dapat diketahui bahwa konstruk remunerasi, budaya organisasi, dan kompetensi pegawai berpengaruh positif terhadap kinerja pegawai pada setiap level Jabatan dan terdapat korelasi hubungan cukup antara konstruk Remunerasi dan Budaya Organisasi untuk seluruh pegawai dan level Jabatan Struktural dan Khusus, serta korelasi hubungan kuat pada level Jabatan Fungsional Umum.
\end{abstract}

Kata kunci: budaya organisasi, kinerja pegawai, kompetensi, remunerasi

\section{ABSTRACT}

Ideally the performance of a Government employees (PNS) aretheir service to the community in living and meeting their daily needs. The final goal of the PNS none other than to improve the welfare of society. Government Remuneration is an integral part of bureaucratic reform policy. Base on the bureaucracy awareness and also the government commitment to create a clean and good governmance. The purpose of bureaucratic reformation is to build a public trust (public trust building) and eliminate the negative image of government bureaucracy. The bureaucratic reformation vision is the establishment of the State apparatus professional and good governance. The mission is to change the pattern of bureaucratic reform mindset, cultural set, and the system of governance. Implementation of remuneration applied at LAPAN on July 2013 granted in accordance with the competences of the employees, work performance of the employees, and work discipline. The objective of this analysis is to analyze the relationship with remuneration and organizational culture, and the influence of

\footnotetext{
*) Korespondensi:

Program Magister Manajemen Sekolah Pascasarjana Institute Pertanian Bogor; Email: maryesa.leny@gmail.com
} 
remuneration to the employee competencies, organizational culture on employee competencies, employee competence to employee performance, remuneration to employee performance and the influence of organizational culture on employee performance. Analysis of the data used in this research is Structural Equation Modeling (SEM). The results of Study in simultaneously and partially are known to constructs remuneration, organizational culture, and employee competence positive effect on the performance of employees at every level positions and there is a correlation relationship between Construct Remunerasi and Cultural Organization to all employees and the level of structural positions and Special and strong correlation relationships at the level of the General Functional.

Key words: competencies, employee performance, organizational culture, remuneration

\section{PENDAHULUAN}

Kinerja pegawai pada dasarnya merupakan tingkat keberhasilan seorang pegawai selama periode tertentu dibandingkan dengan berbagai kemungkinan, seperti standar hasil kerja, target atau sasaran maupun kriteria yang ditentukan terlebih dahulu dan telah disepakati bersama. Kinerja merupakan hasil kegiatan yang telah dilakukan oleh pegawai atau suatu unit organisasi (Veitzal Rivai, 2004). Kinerja baik merupakan tujuan organisasi yang ingin dicapai. Menurut Keith Davis dalam Mangkunegara (2005), ada dua faktor utama yang mengaruhi kinerja individu, yakni kemampuan (ability), dan motivasi kerja (motivation) individu tersebut. Kemampuan individual tergantung dari tingkat pengetahuan (knowledge) yang dimiliki, latar belakang pendidikan, dan keterampilan (skill) yang dikuasai. Motivasi kerja individual tergantung sikap (attitude) sebagai motivasi dasar dan lingkungan yang memengaruhi motivasi tersebut.

Kinerja Pegawai Negeri Sipil (PNS) idealnya merupakan pelayanan terhadap masyarakat dalam menjalani dan memenuhi kebutuhan sehari-hari. Tujuan akhir dari para PNS tak lain ialah meningkatkan kesejahteraan masyarakat. Dibandingkan dengan pegawai swasta, kinerja PNS lebih sulit diukur. Hal ini disebabkan oleh orientasi yang berbeda antara perusahaan/swasta dan pemerintah. Pemerintah yang berorientasi pada pelayanan (service oriented) dalam kegiatan operasionalnya. Mutu layanan yang diberikan pemerintah kepada masyarakat sangat ditentukan oleh kepuasan masyarakat yang menerima layanan.

Remunerasi pemerintahan merupakan bagian yang tidak terpisahkan dari kebijakan reformasi birokrasi. Dilatarbelakangi oleh kesadaran sekaligus komitmen pemerintah untuk mewujudkan clean and good governance. Remunerasi bermakna sangat strategik terhadap suksesnya reformasi birokrasi, mengingat dampak paling nyata terhadap kinerja lembaga akan sangat ditentukan oleh perubahan kultur birokrasi didalam melaksanakan tugas pokoknya. Keberhasilan merubah kultur tersebut akan sangat ditentukan oleh tingkat kesejahteraan anggotanya.

Pada tataran pelaksanaannya, perubahan dan pembaharuan yang dilaksanakan dalam rangka mewujudkan tata pemerintahan yang bersih dan berwibawa tersebut perlu didukung untuk dilaksanakan dengan efektif bila kesejahteraan yang layak dari pegawai yang menjalankannya. Perubahan dan pembaharuan tersebut dilaksanakan untuk menghapus perilaku yang selama ini dinilai buruk, yaitu ditandai oleh indikator buruknya mutu pelayanan publik (lambat, tidak ada kepastian aturan/hukum, berbelit-belit, arogan, minta dilayani atau feodal style, dsb, sarat dengan perilaku KKN (Korupsi, Kolusi, Nepotisme), rendahnya mutu disiplin dan etos kerja aparatur negara, mutu manajemen pemerintahan yang tidak produktif, tidak efektif dan tidak efisien, mutu pelayanan publik yang tidak akuntabel dan tidak transparan. Dengan diperbaharuinya sistem remunerasi pegawai negeri sipil, diharapkan memberikan motivasi bekerja dan disiplin kerja pegawai semakin meningkat, sehingga berdampak kinerja pegawai dalam melayani masyarakat luas semakin baik.

Lembaga Penerbangan dan Antariksa Nasional (LAPAN) merupakan Lembaga Pemerintahan Non Departemen yang mempunyai tugas melaksanakan tugas pemerintahan di bidang penelitian dan pengembangan kedirgantaraan dan pemanfaatannya menurut peraturan perundang-undangan yang berlaku. Dalam rangka mempersiapkan diri menjadi institusi yang dapat mendorong tercapainya kemandirian dalam penguasaan sains dan teknologi kedirgantaraan dan pemanfaatannya dalam mewujudkan kesejahteraan bangsa mendukung pembangunan 
nasional yang berkelanjutan, pada periode tahun 2010-2014, LAPAN tidak hanya memikirkan halhal terkait dengan sains dan teknologi kedirgantaraan, tetapi juga diperlukan perhatian secara menyeluruh baik bersifat penguasaan teknologi maupun yang bersifat dukungan administrasi dan manajemen serta pembinaan sumberdaya.

Tantangan nyata dalam mencapai target sasaran strategis (Renstra) LAPAN pada periode 2010-2014 dan tahun-tahun berikutnya seperti tertuang dalam Renstra LAPAN adalah menyiapkan SDM aparatur secara terpadu dan berkelanjutan. Pengelolaan SDM secara bertanggungjawab dilakukan sejak rekruitmen sampai dengan pensiun. Pengelolaan SDM aparatur LAPAN yang memberikan arah kebijakan pembinaan, pengembangan dan pengelolaan SDM sehingga pelaksanaan rekruitmen dilakukan menurut kebutuhan prioritas fokus program/kegiatan LAPAN dan didukung dengan analisis jabatan, serta analisis beban kerja. Demikian pula halnya dengan pengembangan kemampuan SDM dilakukan melalui berbagai media seperti pendidikan dan pelatihan (diklat) dan seminar-seminar yang pelaksanaannya didasarkan suatu evaluasi kebutuhan berdasarkan analisis jabatan dan analisis beban kerja yang memberikan kriteria syarat jabatan dan kompetensi minimal yang diperlukan dalam memangku jabatan tersebut. Diklat dimaksud tidak hanya terkait dengan halhal yang bersifat teknis seperti diklat teknis, profesional, ataupun pendidikan bergelar tetapi juga mencakup diklat perilaku/kepribadian dan diklat kecakapan teknis personal seperti komunikasi, sehingga pegawai tidak hanya memadai dalam kecakapan teknis, tetapi juga memadai dalam kecakapan pengendalian diri, menjaga motivasi dan komunikasi.

Terbangunnya budaya organisasi ditentukan oleh adanya budaya individu dalam organisasi yang dapat berkembang apabila setiap individu dalam organisasi memiliki "komitmen" tinggi dalam Rancangan Undang-Undang Kepegawaian yang akan disebut sebagai Aparatur Sipil Negara (ASN) melaksanakan visi dan misi organisasi. Setiap PNS/ASN atau Aparatur Pemerintah dituntut memiliki komitmen agar kinerja organisasi pemerintah dalam melaksanakan tanggungjawabnya yaitu melindungi, melayani, dan mengatur rakyat dapat dicapai secara optimal.

Keberadaan PNS di era reformasi dan penyelengaraan otonomi daerah sekarang ini memiliki posisi sangat strategik, karena lancar tidaknya, baik buruknya penyelenggaraan pemerintahan dan pelayanan publik, sangat tergantung kepada kompetensi yang dimiliki dan dikuasai oleh PNS.

Tujuan reformasi birokrasi adalah membangun kepercayaan masyarakat (public trust building) dan menghilangkan citra negatif birokrasi pemerintahan. Visi reformasi birokrasi adalah terwujudnya aparatur Negara yang profesional dan kepemerintahan yang baik (good governance). Misi reformasi birokrasi adalah mengubah pola/alam pikiran (mindset), pola budaya (cultural set) dan sistem tata kelola pemerintahan. Sasaran reformasi birokrasi adalah terwujudnya birokrasi yang: bersih, efektif, efisien, produktif, transparan dan terdesentralisasi.

Pelaksanaan remunerasi LAPAN pada Juli Tahun 2013 diberikan berdasarkan kelas jabatan yang telah ditetapkan oleh Kementerian PAN dan RB. Pemberian remunerasi dan perubahan budaya organisasi diharapkan mampu meningkatkan kinerja pegawai yang pada akhirnya berdampak pada peningkatan kinerja Lembaga.

Tujuan penelitian ini adalah untuk menganalisis hubungan remunerasi dan budaya organisasi dan menganalisisi pengaruh remunerasi terhadap kompetensi pegawai, budaya organisasi terhadap kompetensi pegawai, kompetensi pegawai terhadap kinerja pegawai, remunerasi terhadap kinerja pegawai serta pengaruh budaya organisasi terhadap kinerja pegawai di LAPAN.

Penelitian dilakukan di lingkungan LAPAN yang difokuskan pada kajian remunerasi, kompetensi pegawai, budaya organisasi dan kinerja pegawai. Kajian yang dimaksud menganalisis pengaruh remunerasi dan budaya organisasi terhadap kompetensi pegawai guna meningkatkan kinerja pegawai di lingkungan LAPAN.

\section{METODE PENELITIAN}

Penelitian dilakukan di LAPAN yang berlokasi di Padang, Pontianak, Sulawesi Selatan, Papua, Jawa Timur, Garut, Sumedang, Bandung, Bogor, dan Jakarta. Waktu pengambilan data selama 5 bulan, yaitu dari bulan November 2015 sampai dengan Maret 2016.

Penelitian ini sebagian besar menggunakan data primer yang diperoleh di lapangan. Pengambilan data primer diperoleh dengan kuisioner yang telah dipersiapkan. Selain data 
primer juga diambil data sekunder yang berasal dari pihak manajemen dan sumber-sumber penelitian relevan berupa data internal perusahaan serta literatur terkait. Data sekunder gunanya untuk memberikan gambaran umum dalam mendukung hasil penelitian ini.

Populasi penelitian seluruh pegawai yang berjumlah 1258 orang. Teknik pengambilan contoh dalam penelitian ini adalah Stratified Proportional Random Sampling, yaitu penentuan contoh dengan cara memilih responden secara acak dari masing-masing pengelompokkan. Penentuan jumlah contoh berdasarkan Hair et al dalam Ghozali (2008) dan analisis data multivariat menggunakan Structural Equation Modeling (SEM), dengan metode estimasi menggunakan Maximum Likelihood Estimation (MLE), disamping alternatif metode lain seperti GLS atau WLS.

Tabel 1. Contoh penelitian

\begin{tabular}{llcc}
\hline No & Level jabatan & $\begin{array}{c}\text { Rumus jumlah } \\
\text { contoh }\end{array}$ & $\begin{array}{c}\text { Jumlah } \\
\text { contoh }\end{array}$ \\
\hline 1 & Struktur & $(120: 1258) \times 192$ & 18 \\
2 & Khusus & $(665: 1258) \times 192$ & 102 \\
3 & Umum & $(473: 1258) \times 192$ & 72 \\
\hline & Jumlah & & 192 \\
\hline
\end{tabular}

Berdasarkan telaah pustaka tentang analisis pengaruh Remunerasi dan Budaya Organisasi terhadap Kompetensi Pegawai guna meningkatkan Kinerja Pegawai, maka dikembangkan kerangka pemikiran teoritis seperti dimuat pada Gambar 1.

Kerangka pemikiran tersebut merupakan sintesis atau ekstrapolasi dari tinjauan teori yang mencerminkan keterkaitan antara variabel yang diteliti dan merupakan tuntunan untuk memecahkan masalah penelitian serta merumuskan hipotesis.

Dari kerangka pemikiran teoritis yang telah diuraikan, maka diajukan hipotesis berikut:

H1 : Remunerasi berpengaruh nyata terhadap kompetensi pegawai

H2 : Budaya Organisasi berpengaruh nyata terhadap kompetensi pegawai

H3 : Kompetensi pegawai berpengaruh nyata terhadap kinerja pegawai.

H4 : Remunerasi berpengaruh nyata terhadap kinerja pegawai.

H5 : Budaya Organisasi berpengaruh nyata terhadap kinerja pegawai.

H6 : Terdapat hubungan nyata Remunerasi dan Budaya Organisasi.

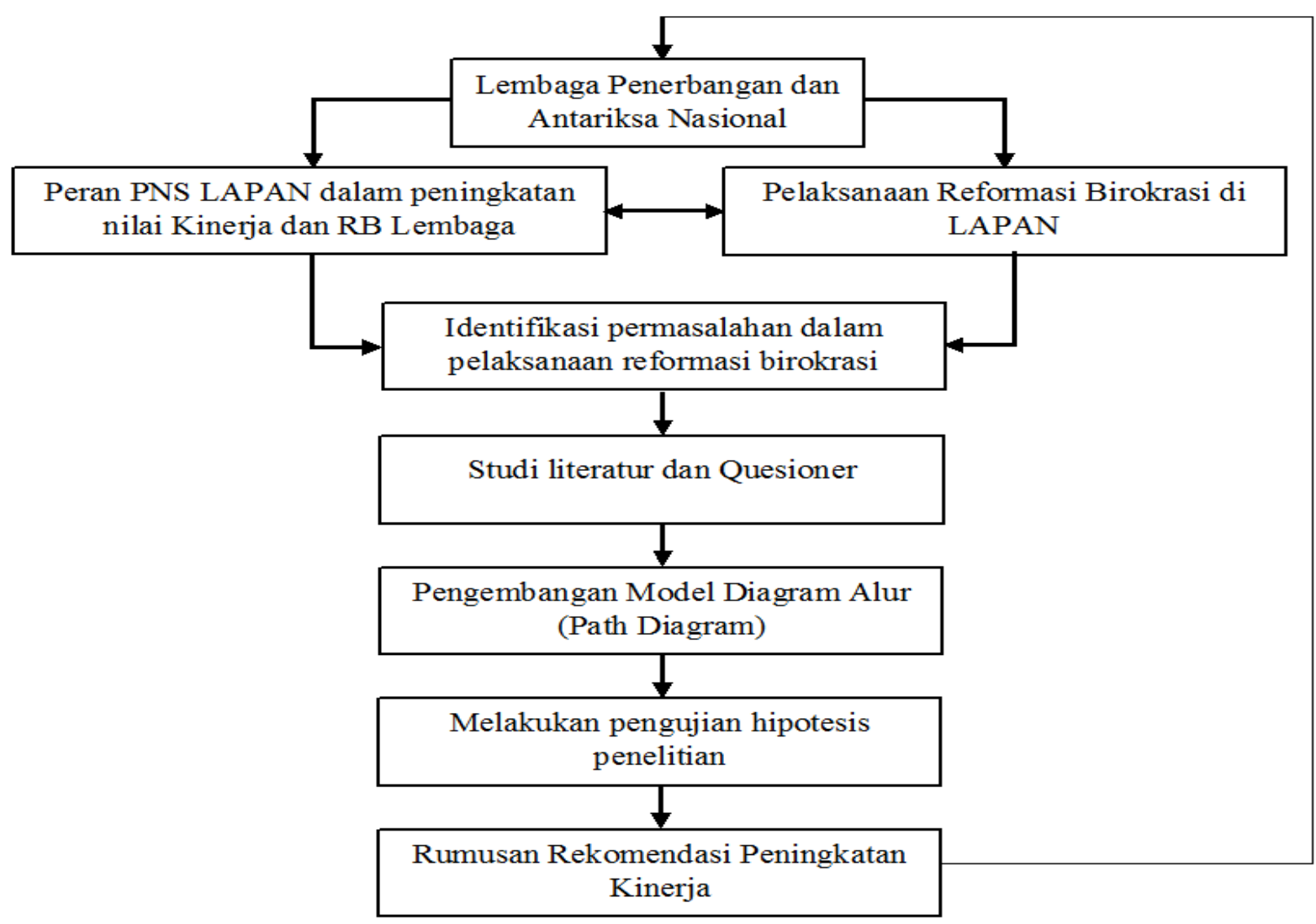

Gambar 1. Kerangka pemikiran teoritis 


\section{HASIL DAN PEMBAHASAN}

Pada bab ini disajikan gambaran data penelitian yang diperoleh dari hasil jawaban reponden, proses pengolahan data dan analisis hasil pengolahan data tersebut. Hasil pengolahan data selanjutnya akan digunakan sebagai dasar untuk analisis dan menjawab hipotesis penelitian yang diajukan.

Analisis data deskriptif digunakan untuk menggambarkan kondisi jawaban responden dari tiga level jabatan, yaitu Jabatan Struktural, Fungsional Tertentu dan Fungsional Umum untuk masing-masing peubah. Hasil jawaban tersebut selanjutnya digunakan untuk mendapatkan tendensi jawaban responden mengenai kondisi masing-masing peubah penelitian.

Analisis data yang adalah digunakan dalam penelitian ini adalah SEM dengan terlebih dahulu melakukan pengujian dimensi-dimensinya dengan confirmatory factor analysis. Evaluasi terhadap model SEM juga akan dianalisis mendapatkan dan mengevaluasi kecocokan model yang diajukan. Setelah diketahui semua hasil pengolahan data, selanjutnya akan dibahas dan yang terakhir adalah menarik kesimpulan-kesimpulan yang didasarkan pada hasil analisis tersebut.

\section{Karakteristik Responden}

Kuesioner penelitian yang diperoleh diolah dan dari hasil pengolahan data dapat disajikan gambaran ringkas profil responden penelitian seperti pada Tabel 2.

\section{Deskripsi Peubah}

Pembahasan dalam penelitian ini menganalisis dengan pendekatan metode penelitian deskriptif dan inferensial. Menurut Sugiono (2007), statistik deskriptif adalah statistik yang digunakan untuk menganalisis data dengan cara menggambarkan data yang terkumpul sebagaimana adanya, tanpa bermaksud membuat kesimpulan yang berlaku umum atau generalisasi dan statitistik Inferensial digunakan bila peneliti ingin mendeskripsikan data sampel dan membuat kesimpulan yang berlaku untuk populasi.

Analisis deskriptif untuk menggambarkan mengenai remunerasi, budaya organisasi, kompetensi pegawai dan kinerja pegawai di lingkungan LAPAN, digunakan dengan melakukan pengklasifikasian jumlah skor perinstrumen dari masing-masing peubah yang diteliti.
Tabel 2. Profil responden penelitian

\begin{tabular}{|c|c|c|c|}
\hline No. & Uraian & Jumlah & $\%$ \\
\hline \multirow[t]{4}{*}{1.} & Jenis Kelamin & & \\
\hline & a. Pria & 58 & 58 \\
\hline & b. Wanita & 42 & 42 \\
\hline & Jumlah & 192 & 100 \\
\hline \multirow[t]{6}{*}{2.} & Usia (Tahun) & & \\
\hline & a. $\leq 30$ & 23 & 12 \\
\hline & b. $31-40$ & 75 & 39 \\
\hline & c. $40-50$ & 47 & 24,5 \\
\hline & d. $\quad 51-60$ & 47 & 24,5 \\
\hline & Jumlah & 192 & 100 \\
\hline \multirow[t]{6}{*}{3.} & Tingkat Pendidikan & & \\
\hline & a. SMA/sederajat & 45 & 23 \\
\hline & b. D-III/D-IV & 14 & 7 \\
\hline & c. S1 & 107 & 56 \\
\hline & d. S2/S3 & 26 & 14 \\
\hline & Jumlah & 192 & 100 \\
\hline \multirow[t]{6}{*}{4.} & Masa Kerja & & \\
\hline & a. $\leq 10$ & 92 & 48 \\
\hline & b. $11-20$ & 20 & 11 \\
\hline & c. $21-30$ & 62 & 32 \\
\hline & d. $\quad \geq 31$ & 18 & 9 \\
\hline & Jumlah & 192 & 100 \\
\hline
\end{tabular}

Sumber: Bagian Kepegawaian LAPAN

Berdasarkan analisis dan perhitungan, terlihat nilai skor Remunerasi dengan frekuensi atau jumlah responden terbanyak nilai 6 pada sejumlah 109 reponden atau 56,77\% atau lebih dari separuh responden.

Nilai skor Budaya Organisasi dengan frekuensi atau jumlah responden terbanyak nilai 5 dan 6 pada sejumlah 117 atau 60,93\% atau lebih dari separuh responden. Nilai skor Kompetensi Pegawai dengan frekuensi atau jumlah responden terbanyak nilai 5 dan 6 pada sejumlah 102 atau $53,12 \%$ atau lebih dari separuh responden. Nilai skor Kinerja Pegawai dengan frekuensi atau jumlah responden terbanyak nilai 5 dan 6 pada sejumlah 97 atau $50,52 \%$ atau lebih dari separuh responden.

\section{Proses Analisis Data dan Pengujian Model Penelitian}

Proses analisis data dan pengujian model penelitian akan menjelaskan tentang langkahlangkah analisis yang digunakan dalam penelitian ini. Langkah-langkah tersebut mengacu pada 8 langkah proses analisis SEM sebagaimana dikemukakan oleh Ferdinand (2006). Adapun urutan langkah-langkah analisis tersebut meliputi: 
1. Menyusun Diagram Alur (Path Diagram) Setelah pengembangan model berbasis teori dilakukan maka langkah selanjutnya adalah menyusun model tersebut dalam bentuk diagram.

2. Konversi Diagram Alur Ke dalam Persamaan Model yang telah dinyatakan dalam diagram alur tersebut, dinyatakan ke dalam persamaan struktural. Persamaan yang diperoleh dari path diagram dikonversikan atas: Structural equation yang dirumuskan untuk menyatakan hubungan kausalitas antara berbagai konstruk.

$\mathrm{V}$ endogen $=\mathrm{V}$ eksogen $+\mathrm{V}$ eksogen + error

$\eta 1=\gamma 1 \xi 1+\beta 2 \eta 1+\zeta 1$

$\eta 2=\gamma 1 \xi 1+\beta 2 \eta 1+\zeta 2$

$\eta 3=\gamma 1 \xi 1++\zeta 3$

atau

Kompetensi Pegawai $=\gamma 1$ Remunerasi $+\beta 2$ Budaya Organisasi $+\zeta 1$

Kinerja Pegawai $=\gamma 1$ Remunerasi $+\beta 2$ Budaya Organisasi $+\zeta 2$

Kinerja Pegawai $=\gamma 1$ Kompetensi Pegawai + $\zeta 3$

3. Memilih Matrik Input dan Estimasi Model

Kovarians atau Korelasi.

Matriks input yang digunakan sebagai input adalah matriks kovarians. Hair et al. (Ferdinand, 2006) menyatakan bahwa dalam menguji hubungan kausalitas maka matriks kovarianlah yang diambil sebagai input untuk operasi SEM. Dari hasil pengolahan data yang telah dikumpulkan.

Langkah selanjutnya setelah menyusun sampel kovarian adalah menentukan teknik estimasi. Setelah mengkonversi data menjadi matrik kovarian maka langkah selanjutnya yang dilakukan adalah menentukan teknik estimasi.

\section{Analisis Struktural Equation Modeling}

Analisis SEM secara Full Model untuk menguji model dan hipotesis yang dikembangkan dalam penelitian. Pengujian model dalam SEM dilakukan dengan dua pengujian, yaitu uji kesesuaian model dan uji nyata kausalitas melalui uji koefisien regresi. Analisis SEM dalam penelitian ini ini terbagi menjadi tiga bagian, yaitu Analisis SEM untuk Keseluruhan level jabatan pegawai (192 pegawai), analisis SEM untuk pegawai Fungsional Khusus (120 pegawai) dan analisis SEM untuk pegawai Fungsional Umum (72 pegawai). Hasil pengolahan data untuk analisis SEM terlihat pada Tabel dan Gambar 2:

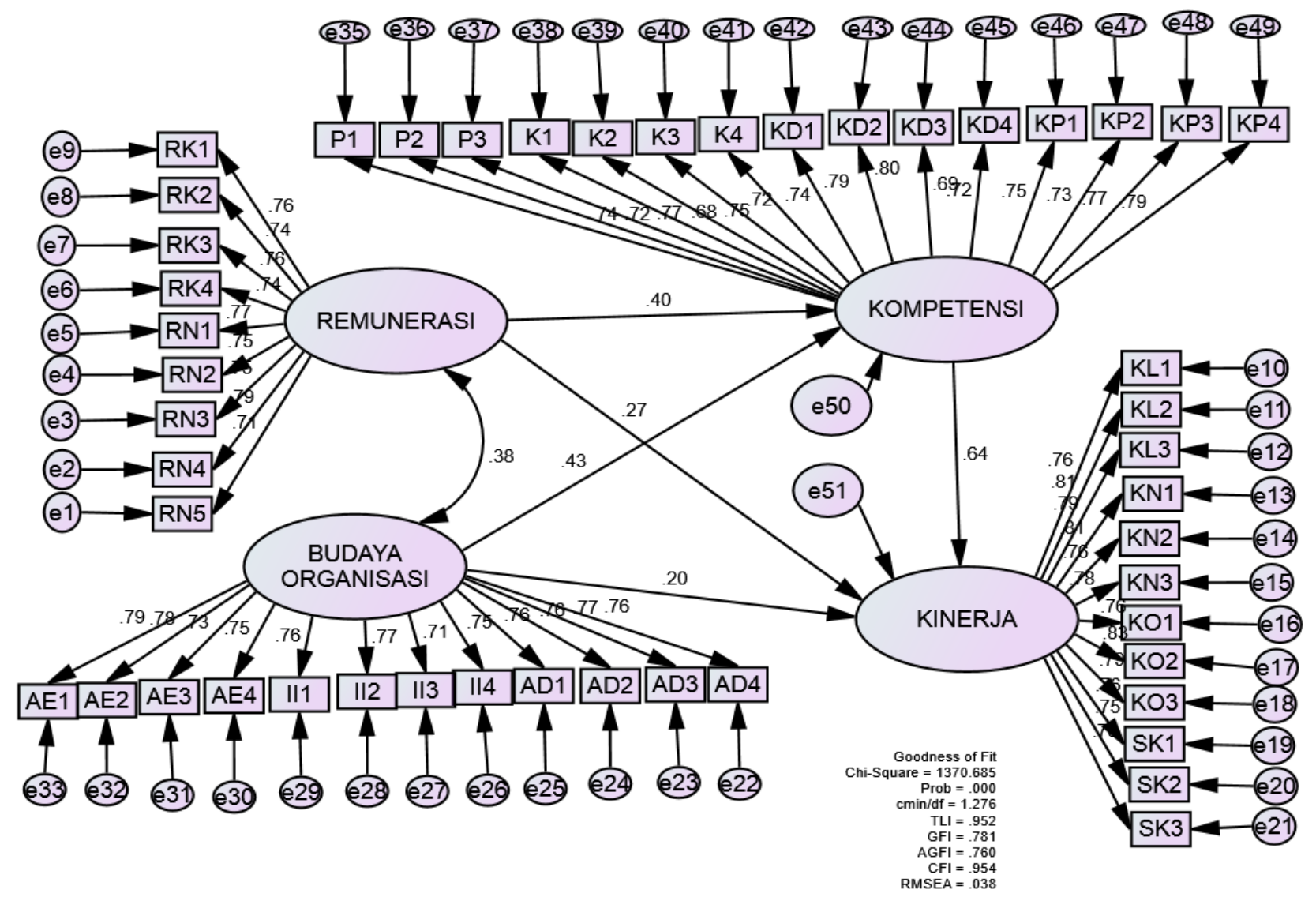

Gambar 2. Hasil uji SEM seluruh pegawai 
Tabel 3. Goodness of fit model seluruh pegawai

\begin{tabular}{lccc}
\hline $\begin{array}{c}\text { Goodness- } \\
\text { Of-Fit }\end{array}$ & Hasil Analisis & $\begin{array}{c}\text { Cut Off } \\
\text { Value }\end{array}$ & $\begin{array}{c}\text { Evaluasi } \\
\text { Model }\end{array}$ \\
\hline $\begin{array}{l}\text { Chi-square } \\
\text { Probability }\end{array}$ & $\begin{array}{c}\chi^{2}=1370.685 \\
\mathrm{P}=0.000\end{array}$ & $\begin{array}{c}<\text { a.df } \\
=0,05\end{array}$ & $\begin{array}{c}\text { Kurang } \\
\text { Baik }\end{array}$ \\
\hline RMSEA & 0.038 & $=0,08$ & Baik \\
\hline GFI & 0.781 & $=0,90$ & $\begin{array}{c}\text { Kurang } \\
\text { baik }\end{array}$ \\
\hline AGFI & 0.760 & $=0,90$ & $\begin{array}{c}\text { Kurang } \\
\text { baik }\end{array}$ \\
CMIN/DF & 1.276 & $=2$ & Baik \\
\hline TLI & 0.952 & $=0,90$ & Baik \\
\hline CFI & 0.954 & $=0,90$ & Baik \\
\hline
\end{tabular}

Sumber: data primer yang diolah, 2016.

Hasil pengujian full model untuk seluruh pegawai menunjukkan bahwa model dapat dikategorikan memenuhi kriteria fit, hal ini didasarkan lebih dari sebagian kriteria adalah terpenuhi dengan baik. Hasil perhitungan uji khikuadrat pada full model memperoleh nilai khikuadrat 1370.685 masih dibawah tabel untuk derajat kebebasan 521 pada taraf nyata $5 \%$ sebesar 575,208 . Nilai peluang sebesar 0,000 yang mana nilai tersebut di bawah 0,05. Nilai GFI 0,781 lebih kecil dari 0,90 (marjinal), Nilai AGFI 0,760 lebih kecil dari 0,90 (marjinal). Nilai CMIN/DF 1,276 masih di bawah 2. Nilai TLI 0,952 masih diatas 0,90. Nilai CFI 0,954 masih di atas 0,90 dan nilai RMSEA 0,038 masih di bawah 0,08. Hasil tersebut menunjukkan bahwa model keseluruhan memenuhi kriteria model fit.

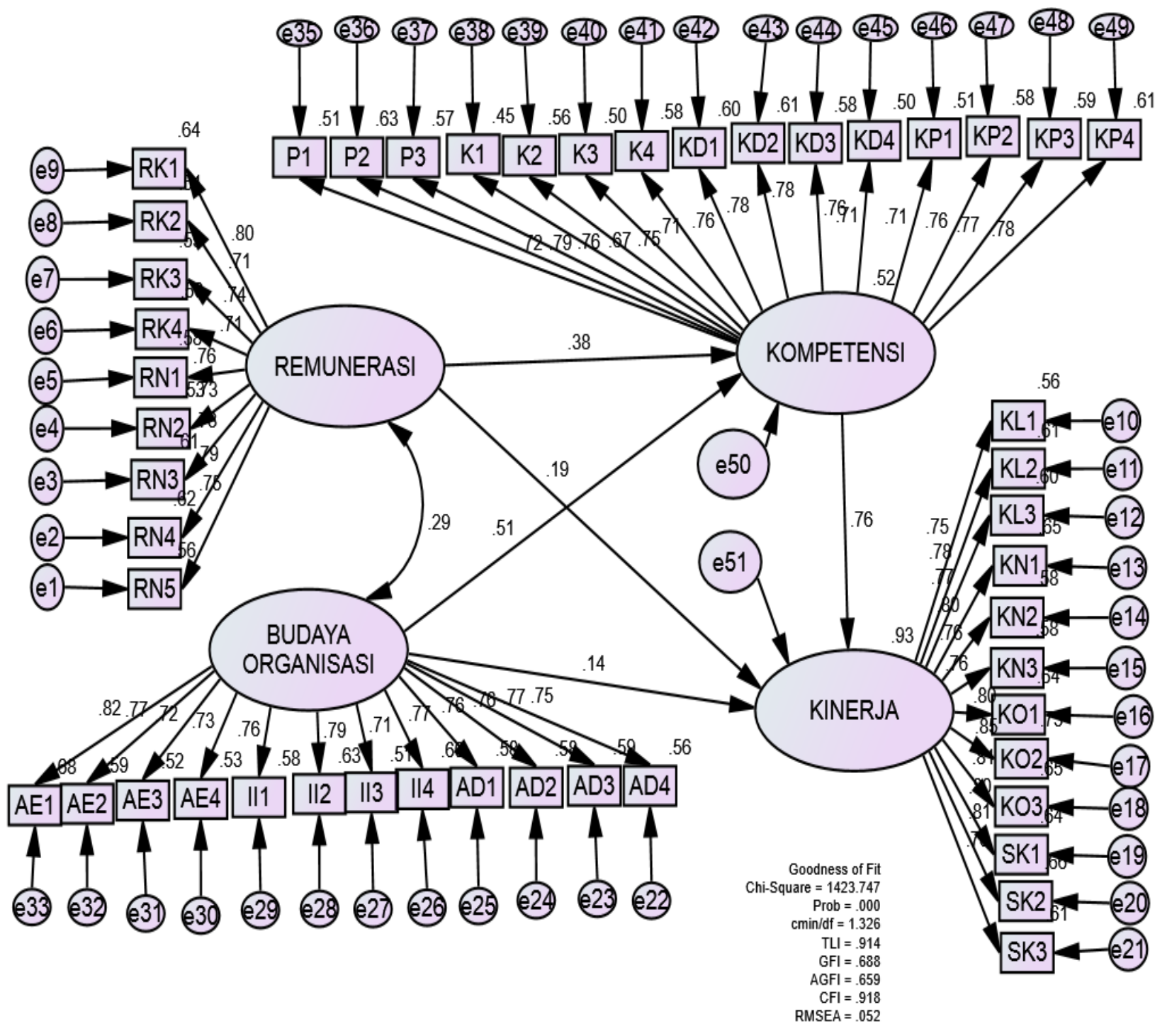

Gambar 3. Hasil uji SEM pegawai fungsional khusus 


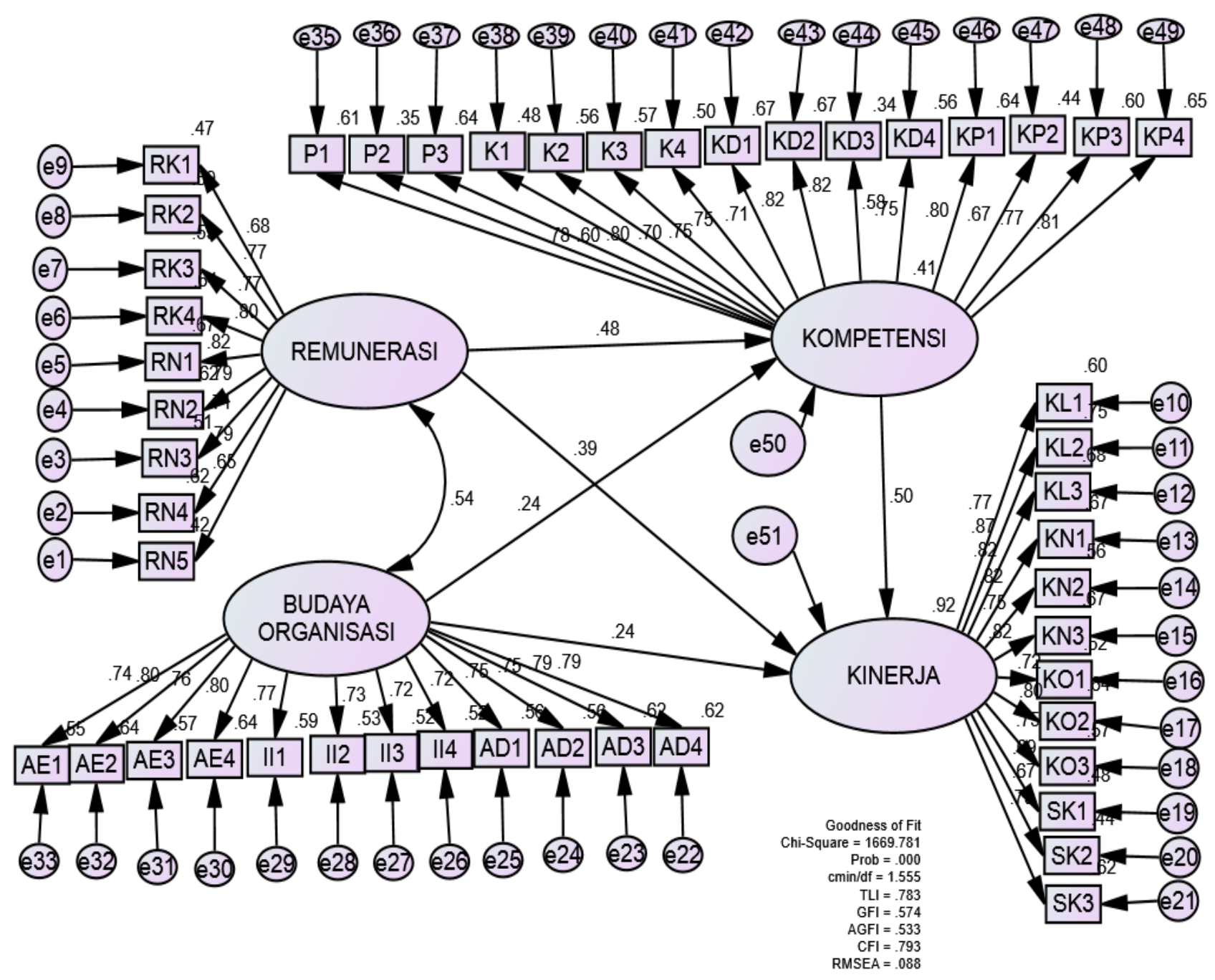

Gambar 4. Hasil uji SEM pegawai fungsional umum

Tabel 4. Goodness of fit model pegawai fungsional khusus

\begin{tabular}{lccc}
\hline $\begin{array}{c}\text { Goodness- } \\
\text { Of-Fit }\end{array}$ & Hasil Analisis & $\begin{array}{c}\text { Cut Off } \\
\text { Value }\end{array}$ & $\begin{array}{c}\text { Evaluasi } \\
\text { Model }\end{array}$ \\
\hline $\begin{array}{l}\text { Chi-square } \\
\text { Probability }\end{array}$ & $\begin{array}{c}\chi^{2}=1423,747 \\
\mathrm{P}=0.000\end{array}$ & $\begin{array}{c}<\boldsymbol{\alpha} \text {.df } \\
=0,05\end{array}$ & Kurang Baik \\
\hline RMSEA & 0,052 & $=0,08$ & Baik \\
\hline GFI & 0,688 & $=0,90$ & Kurang baik \\
\hline AGFI & 0,659 & $=0,90$ & Kurang baik \\
\hline CMIN/DF & 1,326 & $=2$ & Baik \\
\hline TLI & 0,914 & $=0,90$ & Baik \\
CFI & 0,918 & $=0,90$ & Baik \\
\hline
\end{tabular}

Sumber: data primer yang diolah, 2016.

Hasil pengujian full model untuk pegawai fungsional Khusus menunjukkan bahwa model dapat dikategorikan memenuhi kriteria fit, hal ini didasarkan lebih dari sebagian kriteria adalah terpenuhi dengan baik. Hasil perhitungan uji khikuadrat pada full model memperoleh nilai khikuadrat 1423,747 masih dibawah tabel untuk derajat kebebasan 521 pada taraf nyata 5\% sebesar
575,208 . Nilai peluang 0,000 di bawah 0,05 . Nilai GFI 0,688 lebih kecil dari 0,90 (marjinal), Nilai AGFI 0,659 lebih kecil dari 0,90 (marjinal). Nilai CMIN/DF 1,326 masih di bawah 2. Nilai TLI 0,914 masih di atas 0,90. Nilai CFI 0,954 masih di atas 0,90 dan nilai RMSEA 0,052 masih di bawah 0,08. Hasil tersebut menunjukkan bahwa model keseluruhan memenuhi kriteria model fit.

Tabel 5. Goodness of fit model pegawai fungsional umum

\begin{tabular}{lccc}
$\begin{array}{c}\text { Goodness- } \\
\text { Of-Fit }\end{array}$ & Hasil Analisis & $\begin{array}{c}\text { Cut Off } \\
\text { Value }\end{array}$ & $\begin{array}{c}\text { Evaluasi } \\
\text { Model }\end{array}$ \\
\hline $\begin{array}{l}\text { Chi-square } \\
\text { Probability }\end{array}$ & $\begin{array}{c}\chi^{2}=1669,781 \\
\mathrm{P}=0.000\end{array}$ & $\begin{array}{c}<\text { a.df } \\
=0,05\end{array}$ & Kurang Baik \\
\hline RMSEA & 0,088 & $=0,08$ & Kurang Baik \\
\hline GFI & 0,574 & $=0,90$ & Kurang Baik \\
\hline AGFI & 0,533 & $=0,90$ & Kurang Baik \\
\hline CMIN/DF & 1,555 & $=2$ & Baik \\
\hline TLI & 0,783 & $=0,90$ & Kurang Baik \\
CFI & 0,793 & $=0,90$ & Kurang Baik \\
\hline
\end{tabular}


Hasil pengujian full model untuk pegawai fungsional Umum menunjukkan bahwa model dapat dikategorikan tidak memenuhi kriteria fit, hal ini didasarkan lebih dari sebagian kriteria adalah tidak terpenuhi dengan baik. Hasil perhitungan uji khi-kuadrat pada full model memperoleh nilai khi-kuadrat 1370.685 masih di bawah tabel untuk derajat kebebasan 521 pada taraf nyata $5 \%$ sebesar 575,208 . Nilai peluang 0,000 di bawah 0,05. Nilai GFI 0,574 lebih kecil dari 0,90 (marjinal), Nilai AGFI 0,533 lebih kecil dari 0,90 (marjinal). Nilai CMIN/DF 1,555 masih di bawah 2. Nilai TLI 0,783 masih di bawah 0,90. Nilai CFI 0,793 masih di bawah 0,90 dan nilai RMSEA 0,088 masih di atas 0,08. Hasil tersebut menunjukkan bahwa model keseluruhan tidak memenuhi kriteria model fit.

\section{Pengujian Hipotesis Penelitian}

Setelah tahap-tahap pengujian dilakukan, maka langkah selanjutnya adalah pengujian hipotesis penelitian yang diajukan pada Bab III. Pengujian ini didasarkan pengolahan data penelitian dengan analisis SEM, yaitu menganalisis nilai regresi yang ditampilkan pada table Regression Weights Analisis SEM. Pengujian hipotesis dilakukan dengan menganalisis nilai Critical Ratio (CR) dan nilai Probability (P) hasil olah data, dibandingkan dengan batasan statistik yang disyaratkan, yaitu di atas 1,96 untuk nilai $C R$ dan dibawah 0,05 untuk nilai $\mathrm{P}$ (probabilitas).

Apabila hasil olah data menunjukkan nilai yang memenuhi syarat tersebut, maka hipotesis penelitian dapat diterima. Pada penelitian ini diajukan enam hipotesis dengan pengujian untuk seluruh level jabatan, jabatan struktural dan khusus dikelompokan pada satu level jabatan serta jabatan umum yang selanjutnya pembahasa dilakukan dibagian berikut.

\section{Pengaruh Remunerasi Terhadap Kompetensi Pegawai}

Dari pengolahan data diketahui nilai $C R$ dan $\mathrm{P}$ pada pengaruh remunerasi terhadap kompetensi pegawai pada setiap level jabatan di LAPAN dimuat pada Tabel 6 .

Tabel 6. Hasil Uji Pengaruh Remunerasi terha-dap Kompetensi Pegawai

\begin{tabular}{clll}
\hline $\begin{array}{c}\text { Level } \\
\text { jabatan }\end{array}$ & $\begin{array}{c}\text { Seluruh } \\
\text { pegawai }\end{array}$ & $\begin{array}{c}\text { Struktural dan } \\
\text { khusus }\end{array}$ & Umum \\
\hline Nilai CR \& P & $\mathrm{CR}=5,312$ & $\mathrm{CR}=4,366$ & $\mathrm{CR}=3,267$ \\
& $\mathrm{P}=0,000$ & $\mathrm{P}=0,000$ & $\mathrm{P}=0,001$ \\
Hasil uji & Diterima & Diterima & Diterima \\
\hline
\end{tabular}

Hasil kedua nilai ini memberikan informasi bahwa pengaruh remunerasi terhadap kompetensi pegawai pada LAPAN dapat diterima, karena memenuhi syarat di atas 1,96 untuk $C R$ dan di bawah 0,05 untuk nilai $\mathrm{P}$, dapat dikatakan bahwa hipotesis 1 dapat diterima.

Hal ini sejalan dengan teori Tohardi dalam Notoatmodjo (2009) mengemukan bahwa kompensasi dihitung berdasarkan evaluasi pekerjaan, perhitungan kompensasi berdasarkan evaluasi pekerjaan tersebut dimaksudkan untuk mendapatkan pemberian kompensasi yang mendekati kelayakan (worth) dan keadilan (equity). Karena bila kompensasi dirasakan tidak layak dan tidak adil oleh para karyawan maka tidak mustahil hal tersebut merupakan sumber kecemburuan sosial. Penelitian Pasaribu (2013) menunjukan remunerasi dan motivasi berprestasi berpengaruh terhadap kinerja, baik secara simultan maupun parsial.

\section{Pengaruh Budaya Organisasi terhadap Kompe- tensi Pegawai}

Dari pengolahan data diketahui nilai $C R$ dan $\mathrm{P}$ berpengaruh pada budaya organisasi terhadap kompetensi pegawai di setiap level jabatan di LAPAN dimuat pada Tabel 7.

Tabel 7. Hasil uji pengaruh budaya organisasi terhadap kompetensi pegawai

\begin{tabular}{clll}
\hline $\begin{array}{c}\text { Level } \\
\text { jabatan }\end{array}$ & $\begin{array}{c}\text { Seluruh } \\
\text { pegawai }\end{array}$ & $\begin{array}{c}\text { Struktural dan } \\
\text { khusus }\end{array}$ & Umum \\
\hline Nilai CR \& P & $\mathrm{CR}=5,744$ & $\mathrm{CR}=5,305$ & $\mathrm{CR}=2,982$ \\
& $\mathrm{P}=0,000$ & $\mathrm{P}=0,000$ & $\mathrm{P}=0,004$ \\
Hasil uji & Diterima & Diterima & Diterima \\
\hline
\end{tabular}

Hasil kedua nilai ini memberikan informasi bahwa pengaruh budaya organisasi terhadap kompetensi pegawai pada LAPAN dapat diterima, karena memenuhi syarat di atas 1,96 untuk CR dan di bawah 0,05 untuk nilai $\mathrm{P}$, maka hipotesis 2 dapat diterima. Hal ini sejalan dengan Riani (2011) bahwa budaya organisasi merupakan sistem dari shared value, keyakinan dan kebiasaankebiasaan dalam suatu organisasi yang saling interaksi dengan struktur formalnya untuk mencipkan norma-norma perilaku. Budaya organisasi mencakup nilai-nilai dan standarstandar yang mengarahkan perilaku pelaku organasasi dan menentukan arah organisasi secara keseluruhan. 


\section{Pengaruh Kompetensi Pegawai terhadap Kinerja Pegawai}

Dari pengolahan data didapatkan nilai CR dan $\mathrm{P}$ pada pengaruh kompetensi pegawai terhadap kinerja pegawai pada setiap level jabatan di LAPAN dimuat pada Tabel 8.

Tabel 8. Hasil uji pengaruh kompetensi pegawai terhadap kinerja pegawai

\begin{tabular}{clll}
\hline $\begin{array}{c}\text { Level } \\
\text { jabatan }\end{array}$ & $\begin{array}{c}\text { Seluruh } \\
\text { pegawai }\end{array}$ & $\begin{array}{c}\text { Struktural dan } \\
\text { khusus }\end{array}$ & Umum \\
\hline Nilai CR \& P & $\mathrm{CR}=8,890$ & $\mathrm{CR}=7,056$ & $\mathrm{CR}=5,317$ \\
& $\mathrm{P}=0,000$ & $\mathrm{P}=0,000$ & $\mathrm{P}=0,000$ \\
Hasil uji & Diterima & Diterima & Diterima \\
\hline
\end{tabular}

Hasil kedua nilai memberikan informasi bahwa pengaruh kompetensi pegawai terhadap kinerja pegawai pada LAPAN dapat diterima, karena memenuhi syarat di atas 1,96 untuk CR dan di bawah 0,05 untuk nilai $P$, dengan maka hipotesis 3 dapat diterima.

Kinerja pegawai dapat diukur dengan kualitas kerja, kuantitas, konsistensi dan sikap, semakin tinggi kinerja yang diharapkan untuk setiap pegawai makan semakin tinggi pula pengetahuan, keterampilan, konsep diri dan nilainilai, serta karakteristrik pribadi yang kuat yang harus dimiliki seorang pegawai sejalan dengan teori yang dikembangkan oleh Spencer \& Spencer dalam Palan (2007).

Hal penelitian ini relevan dengan dengan penelitian sebelumnya yang dilakukan oleh Emmyah (2009) bahwa secara simultan (bersamasama) kompetensi berpengaruh secara signifikan terhadap kinerja pegawai dan Murbijanto (2013) bahwa peubah kompetensi kerja mempunyai pengaruh positif dan signifikan terhadap kinerja pegawai.

\section{Pengaruh Remunerasi terhadap Kinerja Pegawai}

Dari pengolahan data didapatkan nilai $C R$ dan P pada pengaruh remunerasi terhadap kinerja pegawai pada setiap level jabatan di LAPAN dimuat pada Tabel 9.

Tabel 9. Hasil uji pengaruh remunerasi terhadap kinerja pegawai

\begin{tabular}{ccll}
\hline $\begin{array}{c}\text { Level } \\
\text { jabatan }\end{array}$ & $\begin{array}{c}\text { Seluruh } \\
\text { pegawai }\end{array}$ & $\begin{array}{c}\text { Struktural dan } \\
\text { khusus }\end{array}$ & Umum \\
\hline Nilai CR \& P & $\mathrm{CR}=5,843$ & $\mathrm{CR}=3,723$ & $\mathrm{CR}=4,069$ \\
& $\mathrm{P}=0,000$ & $\mathrm{P}=0,000$ & $\mathrm{P}=0,000$ \\
Hasil uji & Diterima & Diterima & Diterima \\
\hline
\end{tabular}

Hasil kedua nilai memberikan informasi bahwa pengaruh remunerasi terhadap kinerja pegawai pada LAPAN dapat diterima, karena memenuhi syarat di atas 1,96 untuk $C R$ dan di bawah 0,05 untuk nilai $P$, maka hipotesis 4 dapat diterima.

Hal tersebut sejalan dengan Notoadmojo (2009) yang menjelaskan beberapa keuntungan dengan diberikannya kompensasi pelengkap, yaitu: (1) meningkatkan semangat kerja dan kesetiaan atau loyalitas para karyawan terhadap organisasi atau perusahaan, (2) menurunkan jumlah absensi para karyawan dan adanya perputaran kerja, (3) mengurangi pengaruh organisasi karyawan terhadap kegiatan organisasi, dan (4) meminimalkan biaya-biaya lembur yang berarti mengefektifkan prestasi kerja karyawan. Ada dua azas penting dalam program pemberian kompensasi (balas jasa) agar balas jasa yang akan diberikan merangsang gairah dan kepuasan kerja karyawan yaitu: (1) azas adil, (2) azas layak dan wajar. Hal ini berarti imbalan dapat secara langsung mempengaruhi kinerja seseorang. Hasil penelitian hipotesis ini relevan dengan penelitian sebelumnya yang dilakukan oleh Budijanto (2012) bahwa ada hubungan yang sangat kuat dan positif antara peubah bebas remunerasi dengan kinerja pegawai pada Lembaga Pemasyarakatan Klas II A Anak Blitar.

\section{Pengaruh Budaya Organisasi terhadap Kinerja Pegawai}

Dari pengolahan data didapatkan nilai CR dan $P$ pada pengaruh budaya organisasi terhadap kinerja pegawai pada setiap level jabatan di LAPAN dimuat pada Tabel 10.

Tabel 10. Hasil uji pengaruh budaya organisasi terhadap kinerja pegawai

\begin{tabular}{clll}
\hline $\begin{array}{c}\text { Level } \\
\text { jabatan }\end{array}$ & $\begin{array}{c}\text { Seluruh } \\
\text { pegawai }\end{array}$ & $\begin{array}{c}\text { Struktural dan } \\
\text { khusus }\end{array}$ & Umum \\
\hline Nilai CR \& P & $\mathrm{CR}=4,780$ & $\mathrm{CR}=2,604$ & $\mathrm{CR}=3,389$ \\
& $\mathrm{P}=0,000$ & $\mathrm{P}=0,009$ & $\mathrm{P}=0,000$ \\
Hasil uji & Diterima & Diterima & Diterima \\
\hline
\end{tabular}

Hasil kedua nilai memberikan informasi bahwa pengaruh budaya organisasi terhadap kinerja pegawai pada LAPAN dapat diterima, karena memenuhi syarat di atas 1,96 untuk CR dan di bawah 0,05 untuk nilai $\mathrm{P}$, maka hipotesis 5 dapat diterima.

Hal ini sejalan dengan penelitian Hermina \& Zain (2011) bahwa budaya organisasi berpengaruh terhadap kinerja pegawai melalui peubah motivasi dan komitmen; dan penelitian Koesmono (2005) tentang budaya organisasi berpengaruh terhadap kinerja. 


\section{Hubungan Remunerasi dengan Budaya Organisasi}

Dari pengolahan data didapatkan nilai korelasi pada hubungan Remunerasi dan Budaya Organisasi pada setiap level jabatan di LAPAN dimuat pada Tabel 11.

Tabel 11. Hasil uji hubungan antara remunerasi dengan budaya organisasi

\begin{tabular}{lccc}
\hline Level jabatan & $\begin{array}{c}\text { Seluruh } \\
\text { pegawai }\end{array}$ & $\begin{array}{c}\text { Struktural dan } \\
\text { khusus }\end{array}$ & Umum \\
\hline Nilai korelasi & $\begin{array}{c}0,381 \\
\text { Moderat }\end{array}$ & $\begin{array}{c}\text { Moderat } \\
\text { Hasil uji }\end{array}$ & Kuat \\
\hline
\end{tabular}

Hasil pengolahan data ini memberikan informasi bahwa hubungan Remunerasi dan Budaya Organisasi pada seluruh pegawai dan level jabatan struktural dan khusus di LAPAN menunjukan hubungan yang Moderat/Sedang, dengan ukuran antara 0,25-0,50 dan pada level jabatan umum ditunjukan hubungan kuat, dengan ukuran 0,51-0,75.

\section{Analisis Pengaruh Peubah}

Analisis pengaruh dilakukan untuk menganalisis kekuatan pengaruh antar konstruk, baik pengaruh langsung, tidak langsung dan pengaruh totalnya. Efek langsung (direct effect) tidak lain adalah koefisien dari semua garis koefisien dengan anak panah satu ujung. Efek tidak langsung (indirect effect) adalah efek muncul dari sebuah peubah antara. Efek total (total effect) adalah efek dari berbagai hubungan (Ferdinand, 2006).

Berdasarkan Gambar 5 didapatkan seluruh pegawai setiap peubah dalam penelitian ini berpengaruh positif, yaitu remunerasi dan budaya organisasi berpengaruh terhadap kompetensi pegawai guna meningkatkan kinerja pegawai.

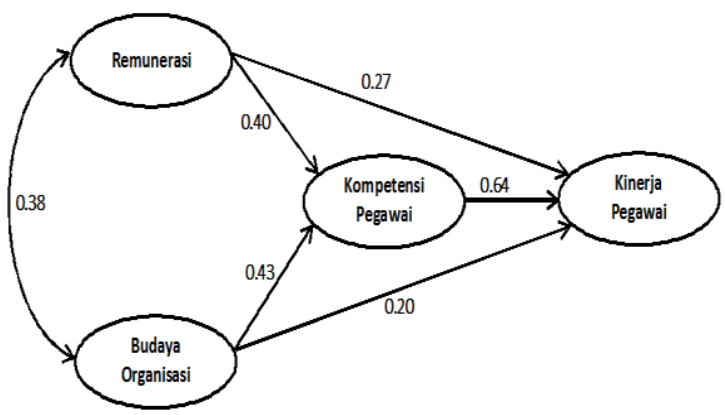

Gambar 5. Diagram pengaruh seluruh pegawai

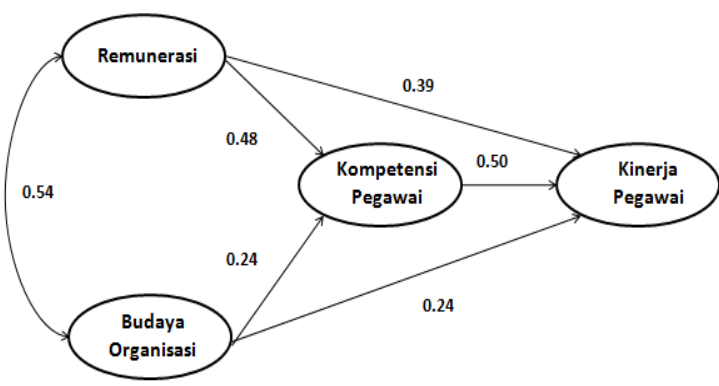

Gambar6. Diagram pengaruh pegawai fungsional khusus

Berdasarkan Gambar 6 didapatkan pegawai fungsional khusus setiap peubah dalam penelitian ini berpengaruh positif, yaitu remunerasi dan budaya organisasi berpengaruh terhadap kompetensi pegawai guna meningkatkan kinerja pegawai.

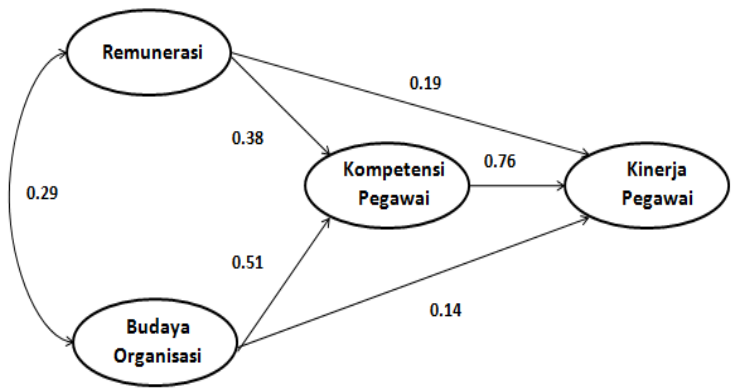

Gambar 7. Diagram pengaruh pegawai fungsional umum

Berdasarkan gambar didapatkan pegawai fungsional umum setiap peubah dalam penelitian ini berpengaruh positif, yang dapat diartikan bahwa remunerasi dan budaya organisasi berpengaruh terhadap kompetensi pegawai guna meningkatkan kinerja pegawai.

Berdasarkan hasil koefisien SEM terlihat pengaruh langsung, tidak langsung, dan pengaruh total antar peubah yang dimuat pada Tabel 12-14.

\section{Pengaruh langsung (Direct effect atau $D E$ )}

Tabel 12. Pengaruh langsung

\begin{tabular}{llccc}
\hline \multicolumn{1}{c}{ Pengaruh } & Terhadap & $\begin{array}{c}\text { Seluruh } \\
\text { pegawai }\end{array}$ & $\begin{array}{c}\text { Struktural } \\
\text { \& khusus }\end{array}$ & Umum \\
\hline $\begin{array}{l}\text { Remunerasi } \\
\text { Budaya } \\
\text { organisasi } \\
\text { Kompetnesi }\end{array}$ & $\begin{array}{l}\text { Kompetensi } \\
\text { Kompetensi }\end{array}$ & $\begin{array}{l}0,40 \\
0,43\end{array}$ & 0,38 & 0,48 \\
& $\begin{array}{l}\text { Kegawa } \\
\text { pegawai }\end{array}$ & 0,64 & 0,76 & 0,24 \\
Remunerasi & $\begin{array}{l}\text { Kinerja } \\
\text { pegawai }\end{array}$ & 0,27 & 0,19 & 0,39 \\
$\begin{array}{l}\text { Kudaya } \\
\text { Krganisasi }\end{array}$ & $\begin{array}{l}\text { pegawai } \\
\text { pegawa }\end{array}$ & $0 ., 20$ & 0,14 & 0,24 \\
\hline
\end{tabular}


Dari Tabel 12 hasil estimasi pengaruh langsung untuk masing-masing konstruk diperoleh koefisien path (standardized regression weights) dengan uraian setiap hipotesis berikut:

1. Hipotesis 1. Hasil estimasi pengaruh langsung konstruk Remunerasi terhadap konstruk Kompetensi diperoleh koefisien path (standardized regression weights) 0,40 (positif) pada LAPAN. Pada level Jabatan Struktural dan Fungsional Khusus serta Level Fungsional Umum remunerasi juga berpengaruh langsung secara positif dengan koefisien path (standardized regression weights) 0,38 (positif) dan 0,48 (positif).

2. Hipotesis 2. Hasil estimasi pengaruh langsung konstruk Budaya Organisasi terhadap konstruk Kompetensi diperoleh koefisien path (standardized regression weights) 0,32 (positif) pada LAPAN. Pada level Jabatan Struktural dan Fungsional Khusus serta Level Fungsional Umum remunerasi berpengaruh langsung positif dengan koefisien path (standardized regression weights) 0,51 (positif) dan 0,24 (positif).

3. Hipotesis 3. Hasil estimasi pengaruh langsung konstruk Kompetensi pegawai terhadap konstruk Kinerja Pegawai diperoleh koefisien path (standardized regression weights) 0,64 (positif) pada LAPAN. Pada level Jabatan Struktural dan Fungsional Khusus, serta Level Fungsional Umum remunerasi juga berpengaruh langsung positif dengan koefisien path (standardized regression weights) 0,76 (positif) dan 0,50 (positif). Hal ini sejalan dengan penelitian Emmyah (2009) bahwa secara simultan (bersama-sama) kompetensi berpengaruh secara nyata terhadap kinerja pegawai dan Murbijanto (2013) bahwa peubah kompetensi kerja mempunyai pengaruh positif dan nyata terhadap kinerja pegawai.

4. Hipotesis 4. Hasil estimasi pengaruh langsung konstruk Remunerasi terhadap konstruk Kinerja Pegawai diperoleh koefisien path (standardized regression weights) 0,27 (positif) pada LAPAN. Pada level Jabatan Struktural dan Fungsional Khusus serta Level Fungsional Umum remunerasi juga berpengaruh langsung positif dengan koefisien path (standardized regression weights) 0,19 (positif) dan 0,39 (positif).

5. Hipotesis 5. Hasil estimasi pengaruh langsung konstruk Budaya Organisasi terhadap konstruk Kinerja Pegawai diperoleh koefisien path (standardized regression weights) 0,20 (positif) pada LAPAN. Pada level Jabatan
Struktural dan Fungsional Khusus serta Level Fungsional Umum remunerasi juga berpengaruh langsung positif dengan koefisien path (standardized regression weights) 0,14 (positif) dan 0,24 (positif).

\section{Pengaruh tidak langsung (Indirect Effect atau IE)}

Berdasarkan Tabel 13 dapat disimpulkan remunerasi dapat berpengaruh secara tidak langsung melalui kompetensi pegawai berpengaruh positif dan nyata terhadap kinerja pegawai. Ini berarti bila remunerasi dan budaya organisasi meningkat, maka akan meningkatkan Kompetensi pegawai yang kemudian akan meningkatkan kinerja pegawai, serta sebaliknya menurunnya remunerasi dan budaya organisasi akan menurunkan kompetensi pegawai yang kemudian akan menurunkan kinerja pegawai.

Hasil penelitian ini mendukung teori Robbins (2002) yang menyatakan bahwa karyawan membentuk suatu persepsi subyektif keseluruhan mengenai organisasi berdasarkan pada faktor-faktor seperti toleransi terhadap risiko, penekanan pada tim dan dukungan rekan lain. Persepsi keseluruhan ini menjadi budaya atau kepribadian organisasi tersebut. Persepsi yang mendukung atau tidak mendukung ini lalu mempengaruh kinerja dan kepuasan karyawan, dengan dampak yang lebih besar pada budaya yang lebih kuat. Makin banyak anggota yang menerima nilai-nilai itu, maka makin kuat budaya organisasi yang terjadi. Budaya organisasi yang kuat akan menghasilkan kepuasan kerja dan kinerja tinggi, sebaliknya budaya organisasi lemah akan menciptakan kepuasan kerja dan kinerja rendah.

Hasil penelitian ini juga mendukung teori Armstrong (1998) yang menyatakan bahwa seorang karyawan yang tidak puas atas pekerjaannya dapat dimotivasi bekerja lebih baik lagi untuk memperbaiki dirinya. Dengan adanya motivasi tinggi dan kepuasan kerja baik yang tercermin dari rasa tanggungjawab dan gairah kerja yang menciptakan suatu keinginan bekerja dan memberikan sesuatu yang terbaik untuk pekerjaannya. Pentingnya motivasi dan kepuasan kerja menuntut pimpinan perusahaan untuk peka terhadap kepentingan karyawan. Dalam hal ini, Pimpinan perusahaan melakukan pendekatan tidak hanya terhadap karyawan, tetapi juga terhadap keluarga dan lingkungannya, sehingga perusahaan tahu apa yang menyebabkan karyawan termotivasi dalam bekerja. 
Tabel 13. Pengaruh tidak langsung

\begin{tabular}{lccccc}
\hline \multicolumn{1}{c}{ Pengaruh } & Terhadap & Melalui & $\begin{array}{c}\text { Seluruh } \\
\text { pegawai }\end{array}$ & $\begin{array}{c}\text { Struktur } \\
\text { \& khusus }\end{array}$ & Umum \\
\hline Remunerasi & Kinerja pegawai & Kompetensi & 0,26 & 0,29 & 0,24 \\
Budaya organisasi & Kinerja pegawai & Kompetensi & 0,28 & 0,39 & 0,12 \\
\hline
\end{tabular}

Tabel 14. Pengaruh total

\begin{tabular}{lccccc}
\hline \multicolumn{1}{c}{ Pengaruh } & Terhadap & Melalui & $\begin{array}{c}\text { Seluruh } \\
\text { pegawai }\end{array}$ & $\begin{array}{c}\text { Struktur } \\
\text { \& khusus }\end{array}$ & Umum \\
\hline Remunerasi & Kinerja pegawai & Kompetensi & 0,53 & 0,48 & 0,63 \\
Budaya organisasi & Kinerja pegawai & Kompetensi & 0,48 & 0,53 & 0,36 \\
\hline
\end{tabular}

\section{Pengaruh Total ( Total Effect atau TE)}

Berdasarkan Tabel 14 dapat disimpulkan remunerasi dan budaya organisasi secara keseluruhan melalui kompetensi pegawai berpengaruh positif dan nyata terhadap kinerja pegawai. Ini berarti bahwa bila remunerasi dan budaya organisasi meningkat, maka akan meningkatkan Kompetensi pegawai yang kemudian akan meningkatkan kinerja pegawai dan sebaliknya menurunnya remunerasi dan budaya organisasi akan menurunkan kompetensi pegawai yang kemudian akan menurunkan kinerja pegawai.

\section{KESIMPULAN}

Secara simultan didapatkan konstruk remunerasi, budaya organisasi, dan kompetensi pegawai berpengaruh positif terhadap kinerja pegawai pada setiap level Jabatan di LAPAN dan secara parsial didapatkan konstruk remunerasi, budaya organisasi, dan kompetensi pegawai berpengaruh positif terhadap kinerja pegawai pada setiap level Jabatan di LAPAN, serta terdapat korelasi hubungan yang cukup antara konstruk Rumunerasi dan Budaya Organisasi untuk seluruh pegawai dan level Jabatan Struktural dan Khusus, serta korelasi hubungan yang kuat pada level Jabatan Fungsional Umum di LAPAN.

\section{DAFTAR PUSTAKA}

Budijanto, S. 2012. Pengaruh pemberian Remunerasi terhadap kinerja pegawai Lembaga Pemasyarakatan Klas IIA Anak Blitar. Malang: Jurnal Universitas Islam Negeri Maulana Malik Ibrahim.
Emmyah. 2009. Pengaruh Kompetensi Terhadap Kinerja Pegawai pada Politeknik Negeri Ujung Pandang.

Ferdinand, A. 2006. Metode Penelitian Manajemen. Semarang: Universitas Diponegoro.

Ghozali, I. 2006. Aplikasi Analisis Multivarite dengan SPSS, Cetakan Keempat, Badan Penerbit Universitas Diponerogo, Semarang

Hermina, U.N., D. Zain. 2011. Pengaruh Budaya Organisasi terhadap motivasi kerja, komitmen dan kinerja pegawai SMAN 9 Pontianak. Pontianak: Jurnal Politeknik Negeri.

Koesmono, H.T. 2005. Pengaruh Budaya Organisasi Terhadap Motivasi Dan Kepuasan Kerja Serta Kinerja Pegawai Pada Sub Sektor Industri Pengolahan Kayu Skala Menengah Di Jawa Timur. Surabaya: Jurnal Universitas Kristen Petra. Surabaya.

Mangkunegara, A.A. Anwar Prabu. 2005. Evaluasi Kinerja SDM. Cetakan Keempat. Bandung : Penerbit PT. Refika Aditama.

Murbijanto. 2013. Analisis pengaruh Kompetensi Kerja dan Lingkungan Kerja Fisik terhadap Kinerja Pegawai (Studi Pada Pegawai Dinas Tenaga Kerja Kabupaten Bekasi).

Notoatmodjo, S. 2009. Pengembangan Sumber Daya Manusia. PT Rineka Cipta.Jakarta

Palan, R. (2007) Competency Management: Teknis Mengimplementasikan Manajemen SDM Berbasis Kompetensi untuk Meningkatkan Daya Saing Organisasi. PPM. Jakarta.

Pasaribu, C.B.A. 2013. Pengaruh remunerasi dan motivasi berprestasi terhadap kinerja pegawai pada kantor pengawasan dan pelayanan Bea Cukai Medan. Medan: Jurnal Universtas Sumatera Utara.

Riani, A.L. 2011. Budaya Organisasi. Cetakan Pertama, Edisi Pertama. Yogyakarta: Graha Ilmu. 
Rivai, V. 2004. Manajemen Sumber Daya Manusia Untuk Perusahaan. Jakarta : Murai Kencana.

Sugiyono. 2007. Metode Penelitian Bisnis. Edisi Kedelapan. Bandung: Alfabeta
Sugiyono dan E. Wibowo. 2001. Statistika Penelitian. Edisi I. Bandung: Alfabeta.

Sugiyono. 2007. Metode Penelitian Kuantitatif Kualitatif dan RD. Bandung: Alfabeta. 